\title{
Subcellular Localization of Glucanase and Cellulase in Saprolegnia monoica Pringsheim
}

\author{
By MICHEL FÈVRE \\ Laboratoire de Physiologie Végétale, \\ Laboratoire de Mycologie associé au CNRS, Université Claude Bernard, \\ Lyon I, 43 Boulevard du I I Novembre 19I8, 69 62 I Villeurbanne, France
}

(Received 12 July 1977)

$(\mathrm{I} \rightarrow 3)-\beta$-Glucanase and cellulase, thought to be involved in the growth and branching processes of Saprolegnia monoica hyphae, were mainly localized at the edge of the colony. Autolysis of purified cell walls occurred preferentially in newly-formed walls. This process was also more important in walls of branched hyphae than in those of unbranched mycelium.

Intracellular fractions were separated and characterized by density gradient ultracentrifugation, enzymic tests and electron microscopy. The fractions rich in $\beta$-glucanase and cellulase contained dictyosomes and apical vesicles. In agreement with cytological descriptions of the apex, the present results confirm the role of these 'morphogen' enzymes in hyphal morphogenesis.

\section{INTRODUCTION}

Wall lytic enzymes may be involved in the process of hyphal morphogenesis. Recent results suggest or support their participation in wall growth. There is a positive correlation between the level of $(I \rightarrow 3)-\beta$-glucanase, cellulase and/or proteases and apical growth and branching of the mycelia of Neurospora crassa (Mahadevan \& Mahadkar, 1970), the germination of conidia of Microsporum gypseum (Page \& Stock, 1974), the hormone-induced branching of Achlya (Thomas \& Mullins, I967, I969; Mullins, 1973) and the budding phase of yeast (Maddox \& Hough, I97I; Cortat, I97I). Enzymes capable of degrading wall polymers [proteases and/or $(\mathrm{I} \rightarrow 3)-\beta$-glucanase] have been isolated from the hyphal walls of Neurospora crassa (Mahadevan \& Mahadkar, 1970; Mehta \& Mahadevan, 1975) and from the yeast walls of Schizosaccharomyces (Barras, 1972; Fleet \& Phaff, 1974).

The presence of inhibitors of protein synthesis in the growth medium of Saprolegnia monoica leads to the complete loss of branching capacity of the mycelium and a corresponding decrease in cellulase and $(\mathrm{I} \rightarrow 3)-\beta$-glucanase activities (Fèvre, I972, 1976). In this paper, I describe an attempt to elucidate the location of these two 'morphogen' enzymes in the mycelium of Saprolegnia monoica.

\section{METHODS}

Culture methods. The strain, Saprolegnia monoica Pringsheim no. 53967 Dick, obtained from CBS, Baarn, The Netherlands, was maintained on a wheat flour medium. Liquid cultures were grown in $250 \mathrm{ml}$ Erlenmeyer flasks by inoculating $100 \mathrm{ml}$ of the liquid medium of Machlis (1953) with mycelial discs (4 mm diam.) from plate cultures, and incubating at $23^{\circ} \mathrm{C}$ for 4 days. The mycelium was harvested by filtration through paper in a Buchner funnel and washed with cold distilled water. Plate cultures were grown by inoculating mycelial discs into the centre of Petri dishes which contained Machlis (1953) medium supple- 
mented with $\mathrm{I} 2 \mathrm{~g}$ agar $\mathrm{1}^{-1}$ and covered by a Cellophane film. After 8 days, the colonies were cut in concentric zones with sterile microscalpels, following guidelines drawn under the dishes.

Preparation of extracts. Mycelia from each concentric zone were freeze-dried then ground in a mortar with purified sand ( 3 parts by weight) and $0.01 \mathrm{M}$-Tris/ $\mathrm{HCl}$ buffer $\mathrm{pH} 7 \cdot 2$ (4 parts by volume) to make a thick slurry. After centrifugation $\left(20000 \mathrm{~g}, 20 \mathrm{~min}, 4^{\circ} \mathrm{C}\right)$ the pellet was discarded and the supernatant was kept in ice until used.

For experiments requiring isolated wall fractions, the lyophilized mycelium was ground with sand and buffer as above, and then centrifuged at $1000 \mathrm{~g}$ for $10 \mathrm{~min}$; the pellet was washed eight times with $0.4 \mathrm{M}$ sucrose and distilled water.

Cytoplasmic particles were obtained by mixing and grinding the fresh mycelia in buffer $(0.01 \mathrm{M}-\mathrm{Tris} / \mathrm{HCl}$, $0.5 \mathrm{M}$-sorbitol, $0.00 \mathrm{r} \mathrm{M}$-EDTA, $\mathrm{pH} 7.2$ ) in a Virtis homogenizer for three periods of $30 \mathrm{~s}$ at $4{ }^{\circ} \mathrm{C}$. The wall fraction was discarded after centrifugation at $1000 \mathrm{~g}$ for $10 \mathrm{~min}$ and the particulate fraction was obtained by centrifuging the supernatant at $48000 \mathrm{~g}$ for $30 \mathrm{~min}$. For sucrose density gradient analysis, the particulate fraction, suspended in $2 \mathrm{ml}$ buffer, was layered on to a $30 \mathrm{ml}$ sucrose gradient ( 20 to $50 \%$, w/v) or Urografin (Schering) gradient (containing $0.01 \mathrm{M}-\mathrm{Tris} / \mathrm{HCl} \mathrm{pH} \mathrm{7.2,0.001} \mathrm{M-EDTA)} \mathrm{and} \mathrm{centrifuged} \mathrm{at} 4{ }^{\circ} \mathrm{C}$ in a Beckman L5.50 or MSE centrifuge (SW27 rotor) at $25000 \mathrm{rev}$. $\mathrm{min}^{-1}$. Tests indicated that isopycnic sedimentation of particles was obtained after $4 \mathrm{~h}$ centrifugation. Fractions of 25 drops were collected and analysed for enzyme activities.

Enzyme assays. $\beta$-Glucanase activity [EC 3.2.1.6; I,3-(I,3; [,4)- $\beta$-D-glucan $3(4)$-glucanohydrolase] was assayed by incubating 100 to $300 \mu \mathrm{l}$ of enzyme preparation with $\mathrm{I} \mathrm{ml}$ of glucan substrate $(3 \mathrm{mg}$ laminarin $\mathrm{ml}^{-1}$ in Mcllvaine buffer $\mathrm{pH} 5$ ) at $37^{\circ} \mathrm{C}$ and determining the amounts of reducing sugars or glucose in the mixture after incubation. For each reaction, corresponding controls (lacking enzyme or substrate) were prepared and their activity was subtracted from the activity of the enzyme sample. Cellulase activity [EC 3.2.I.4; I,4-(I,3;1,4)- $\beta$-D-glucan 4 -glucanohydrolase] was assayed by measuring the loss of viscosity caused by $0.25 \mathrm{ml}$ of enzyme preparation in a $2 \%(\mathrm{w} / \mathrm{v})$ solution of hydroxyethylcellulose in Mcllvaine buffer pH 5 at $40^{\circ} \mathrm{C}$ (Courtois \& Bui, 1967). One unit was taken as the amount of enzyme that caused a $I \%$ decrease in viscosity relative to that of a blank. Acid phosphatase [EC 3.1.3.2; orthophosphoricmonoester phosphohydrolase (acid optimum)] and alkaline phosphatase [EC 3. r.3.2; orthophosphoricmonoester phosphohydrolase (alkaline optimum)] were assayed as described by Schurr \& Yagil (197I). ATPase [EC 3.6.1.3; ATP phosphohydrolase] was assayed as described by Nombela, Uruburu \& Villanueva (1974) in the presence of oligomycin (Kulaev, 1973). Succinic INT reductase was determined according to the method of Morré (I97I). NADH cytochrome $c$ reductase [EC I.6.99.3; NADH:cytochrome $c$ oxidoreductase] was determined using the methods described by Tolbert (1974) and Shore \& MacLachlan (1975). $\beta$-Glucosidase [EC 3.2.I.2I; $\beta$-D-glucoside glucohydrolase] was assayed as described by Cortat (1971).

Protein was determined by the method of Lowry et al. (195I). Reducing sugars were estimated with the dinitrosalicylic acid reagent (Miller, 1959), and glucose with the Gluco-kit (DB Merieux) and Glucostat (Worthington) according to the manufacturers' instructions. Total sugars were determined by the anthrone method (Fairbairn, 1953).

Electron microscopy. Gradient fractions were fixed in $2 \%(\mathrm{v} / \mathrm{v})$ glutaraldehyde buffered with $0 . \mathrm{I} \mathrm{M}$ -

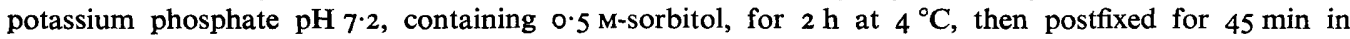
buffered $\mathrm{I} \%(\mathrm{w} / \mathrm{v}) \mathrm{OsO}_{4}$. After dehydration in ethanol, pellets were embedded in Epon. Cytoplasmic membranes in thin sections were stained using alkaline lead citrate.

\section{RESULTS}

\section{Localization of glucanase and cellulase in the fungal colony}

Mycelia grown on Cellophane in Petri dishes were cut in concentric zones and analysed for enzyme activities. $(\mathrm{I} \rightarrow 3)-\beta$-Glucanase and cellulase were mainly localized at the edge of the colony (the extension and branching zone) and their activities decreased with increasing age of the zone. The activities (per $\mathrm{mg}$ freeze-dried mycelium) in the oldest mycelial zone were only $12 \%$ (cellulase) and $40 \%$ (glucanase) of those in the hyphal tip area (Fig. I $a$ ). The specific activities (activity per mg protein) showed the same trend (Fig. I b): activities in the oldest zone were $50 \%$ (glucanase) and $20 \%$ (cellulase) of those in the youngest zone (Fig. 2). The distribution of other enzymes was different. Acid phosphatase, in particular, and, to a lesser extent, $\beta$-glucosidase were localized in the older parts of the mycelium. 

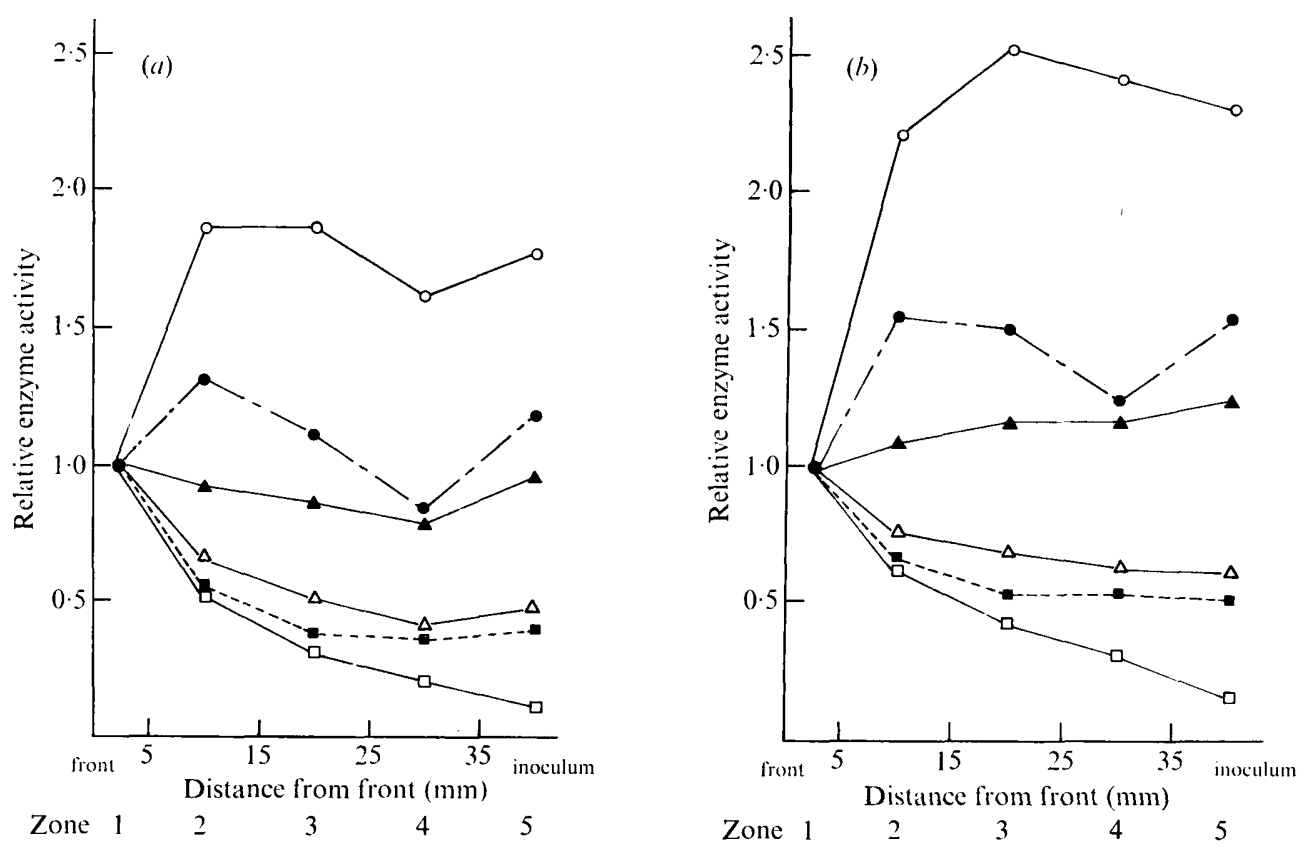

Fig. I. Enzyme activities in different parts of the colony of Saprolegnia monoica. Mycelia grown on Cellophane in Petri dishes were cut in concentric zones, freeze-dried and assayed for enzyme activities, as described in Methods. The activity found in each zone is expressed relative to that found in the apical zone: these activities were expressed $(a)$ per $\mathrm{mg}$ freeze-dried mycelium, or $(b)$ per mg protein. $\bigcirc$, Acid phosphatase; $\boldsymbol{O}$, succinic INT reductase; $\boldsymbol{\Delta}, \boldsymbol{\beta}$-glucosidase; $\square$, cellulase; $\mathbf{n},(\mathrm{I} \rightarrow 3)$ - $\beta$-glucanase (dinitrosalicylic reagent); $\triangle,(\mathrm{I} \rightarrow 3)$ - $\beta$-glucanase (DB Merieux kit).

\section{Glucanases of cell walls - autolysis}

Differential centrifugation has shown that glucanase and cellulase are bound to the cell walls and cytoplasmic particles (Fèvre, Turian \& Larpent, 1974). Wall enzymes can be liberated by the mechanical action of freezing and thawing. The amount of released glucanase is related to the morphology of the mycelium, branched hyphae containing more $\beta$-glucanase than unbranched mycelium (Fèvre, 1976).

Purified walls incubated in Mcllvaine buffer $\mathrm{pH} 5$ at $37^{\circ} \mathrm{C}$ released soluble sugars into the supernatant. Analysis of the products (Fig. $2 b$ ) showed that glucose (tested by Glucostat) represented only a small part of the total sugar released (tested by the anthrone method), suggesting that the major products of autolysis are long-chain soluble glucans, produced by the action of an endo-glucanase in the cell wall. At the same time $(\mathrm{I} \rightarrow 3)-\beta$ glucanase was released (Fig. 2b). Comparison with results for mycelia grown in the presence of DL-p-fluorophenylalanine (Fig. 2a) showed that branched mycelia have a higher autolytic capacity and release more glucanase than unbranched hyphae.

\section{Localization of the sites of autolysis}

Purified walls obtained from different zones of the fungal colony were tested for the release of sugars by autolysis (Table I). The total release of sugar from the youngest zone was nine times greater than that from the oldest zone. In each zone, glucose was always released in small quantities, confirming the endo-mechanism of the autohydrolytic process. Wall preparations also hydrolysed laminarin; the ratio of $(\mathrm{I} \rightarrow 3)-\beta$-glucanase activity in the youngest part of the colony to that in the oldest part was about 2:I. Thus, laminarin was more readily degraded than the macromolecules of the wall. It seems that walls in 


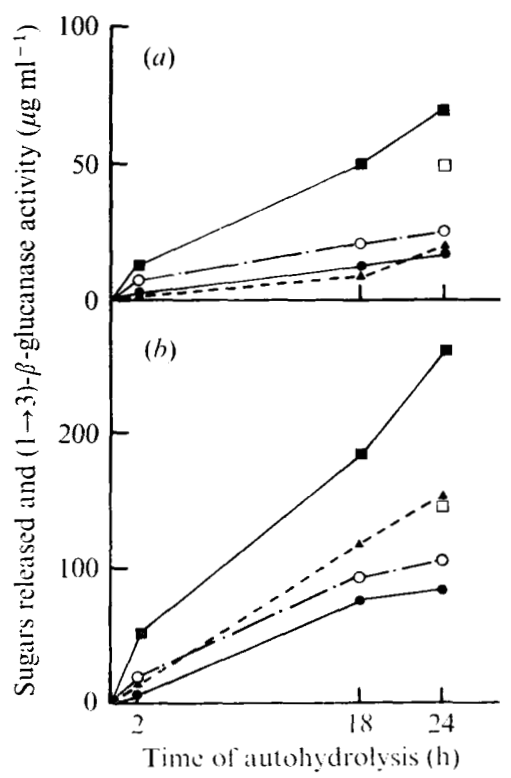

Fig. 2. Autolysis of purified walls of Saprolegnia monoica: (a) walls of unbranched mycelia, grown with DL-p-fluorophenylalanine; $(b)$ walls of branched mycelia. Sugars released by autolysis were tested with: anthrone $(\boldsymbol{\square})$ for total sugar; dinitrosalicylic acid reagent $(\boldsymbol{\Delta})$ for reducing sugar; Gluco-kit $(\bigcirc)$ or Glucostat $(O)$ for glucose. The activity of $(\mathrm{I} \rightarrow 3)$ - $\beta$-glucanase liberated after $24 \mathrm{~h}$ autohydrolysis was tested against laminarin using dinitrosalicylic reagent $(\square)$.

\section{Table I. Total sugars and glucose released by autolysis and $(\mathrm{I} \rightarrow 3)-\beta$-glucanases of} purified cell walls of different parts of the colony of Saprolegnia monoica

Colonies grown on Cellophane film in Petri dishes were cut in concentric zones. The walls of the mycelium of each zone were purified and tested for their autolytic (200 mg walls, $4 \mathrm{ml}, \mathrm{I} 8 \mathrm{~h}$ ) and glucanase (I00 $\mathrm{mg}$ walls, I $\mathrm{ml}$, I h) activities. Results for the different analysis methods are all expressed as glucose $(\mu \mathrm{g})$ equivalents.

\begin{tabular}{|c|c|c|c|c|c|}
\hline \multirow[b]{2}{*}{ Zone } & \multirow{2}{*}{$\begin{array}{c}\text { Distance from colony } \\
\text { edge }(\mathrm{cm})\end{array}$} & \multicolumn{3}{|c|}{ Autolysis } & \multirow{2}{*}{$\begin{array}{c}(\mathrm{I} \rightarrow 3)-\beta \text {-Glucanase } \\
\text { Gluco-kit }\end{array}$} \\
\hline & & Anthrone & Gluco-kit & Glucostat & \\
\hline $\mathbf{I}$ & $0-I$ & 712 & 372 & 24 & 350 \\
\hline 2 & $I-2$ & 456 & 292 & 33 & 300 \\
\hline 3 & $2-3$ & 424 & 260 & 28 & 286 \\
\hline 4 & 3 -inoculum & 84 & 96 & 10 & 202 \\
\hline
\end{tabular}

the younger part of the mycelium could be attacked more easily than older walls, because the difference in sugar released by autolysis between zones I and 4 was greater than the difference in glucanase activity.

\section{Subcellular location of glucanase and cellulase}

Cytoplasmic particles sedimented by centrifugation at $48000 \mathrm{~g}$ were layered on a continuous gradient of sucrose or Urografin. Glucanase was distributed in three different density bands, corresponding to those of the plasma membrane $\left(\mathrm{I} \cdot 19 \mathrm{~g} \mathrm{~cm}^{-3}\right)$, the Golgi apparatus $\left(\mathrm{I} \cdot \mathrm{I} 4 \mathrm{~g} \mathrm{~cm}^{-3}\right)$ and the endoplasmic reticulum (I $\left.\cdot 10 \mathrm{~g} \mathrm{~cm}^{-3}\right)$ (Cortat, I97I) (Fig. 3). Glucanase-rich particles from unbranched mycelium were less abundant and the difference was obvious for the particles of density $I \cdot I 4$ to $I \cdot I I \mathrm{~g} \mathrm{~cm}^{-3}$ (Fig. 4). These densities correspond to those of the cytoplasmic vesicles isolated from yeast buds (Cortat, 197I). Cellulase activity was also distributed in three different density zones. The presence of 


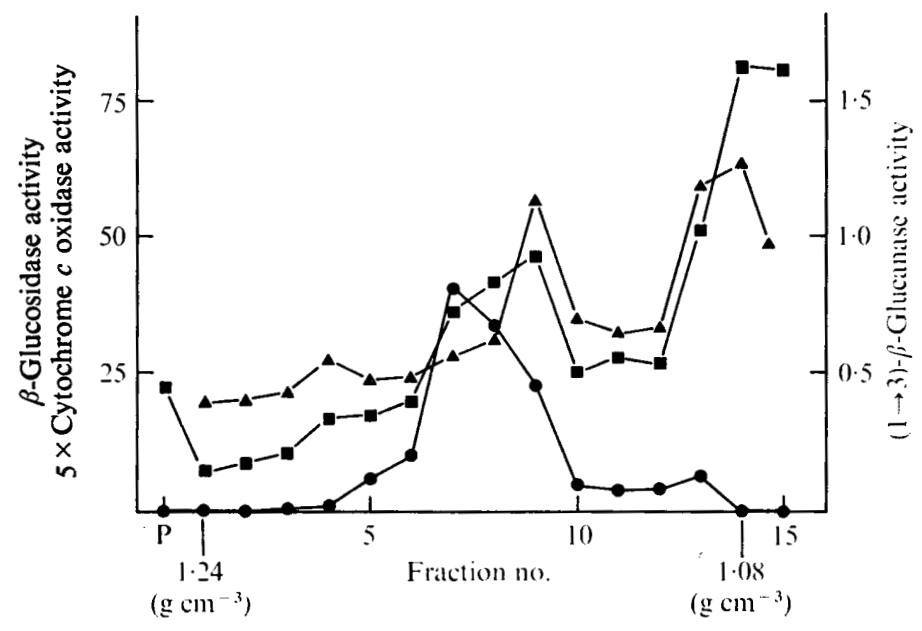

Fig. 3. Distribution of enzyme activities in a continuous density sucrose gradient: cytochrome $c$ oxidase; $\boldsymbol{\square}, \beta$-glucosidase; $\boldsymbol{\Lambda},(\mathrm{I} \rightarrow 3)$ - $\beta$-glucanase. Cytoplasmic particles, prepared as described in Methods, were layered on the sucrose gradient and centrifuged $\left(4 \mathrm{~h}, 26000 \mathrm{rev}\right.$. $\mathrm{min}^{-1}$, SW27 MSE rotor). Activities of cytochrome $c$ oxidase and $\beta$-glucosidase are expressed as change in extinction units per fraction and glucanase activity is expressed as mg glucose released per fraction.

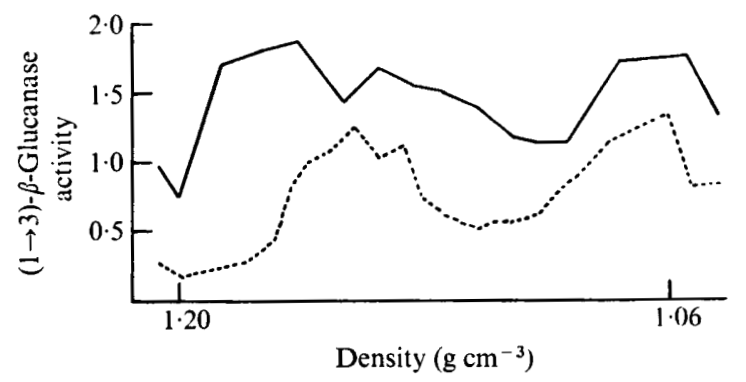

Fig. 4. Distribution of glucanase activity in a continuous density Urografin gradient. Cytoplasmic particles, prepared from branched mycelium $(-)$ or unbranched mycelium, grown with DL-pfluorophenylalanine (--), were layered on the Urografin gradient and centrifuged $(4 \mathrm{~h}, 26000$ rev. $\mathrm{min}^{-1}$, SW 27 MSE rotor). (I $\rightarrow 3$ )- $\beta$-glucanase activities, expressed as mg glucose released in $6 \mathrm{~h}$ per fraction, were corrected to the same amount of protein layered on the gradients.

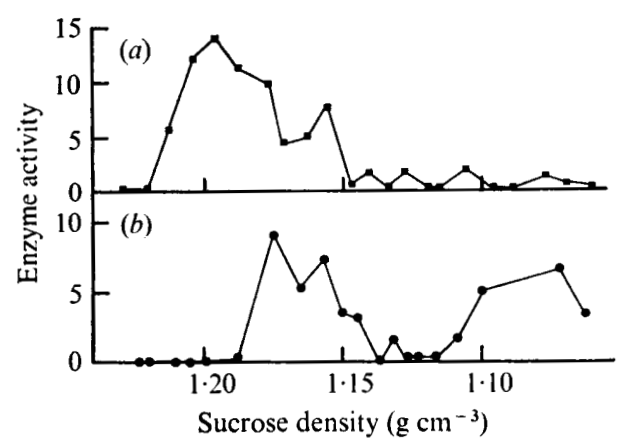

Fig. 5. Distribution of cellulase activity in a continuous density sucrose gradient: (a) $\mathrm{MgCl}_{2}$ present in the extraction buffer and in the gradient; $(b) \mathrm{MgCl}_{2}$ absent. Cytoplasmic particles were layered on the sucrose gradient and centrifuged $\left(4 \mathrm{~h}, 26000 \mathrm{rev}^{-m_{i n}}{ }^{-1}, \mathrm{SW}_{27}\right.$ Beckman rotor). Cellulase activities are expressed in arbitrary units. 


\section{Table 2. Distribution of glucanase and cellulase activities among membrane fractions}

Cytoplasmic particles were prepared as described in Methods and centrifuged on a discontinuous density sucrose gradient. Enzymes were assayed against laminarin (glucanase) and hydroxyethylcellulose (cellulase). For each enzyme, activities are expressed as a percentage of the total activity of that enzyme found in the gradient.

$\begin{array}{ccc}\text { Interface }\left(\mathrm{g} \mathrm{cm}^{-3}\right) & (\mathrm{I} \rightarrow 3)-\beta \text {-Glucanase } & \text { Cellulase } \\ \text { Soluble/I.08 } & \mathrm{I} \cdot 3 & \text { IO } \\ \mathrm{I} \cdot 08 / \mathrm{I} \cdot \mathrm{IO} & \mathrm{II} \cdot 8 & \mathrm{I2} \\ \mathrm{I} \cdot \mathrm{I} / \mathrm{I} \cdot 13 & 30 \cdot 7 & 22 \\ \mathrm{I} \cdot 13 / \mathrm{I} \cdot \mathrm{I} 6 & 34 \cdot 6 & 3 \mathrm{I} \\ \mathrm{I} \cdot \mathrm{I} 6 / \mathrm{I} \cdot \mathrm{I} 7 & \mathrm{I} \cdot 3 & \mathrm{I} 5 \\ \mathrm{I} \cdot \mathrm{I} 7 / \mathrm{I} \cdot 20 & 5 \cdot 3 & 10\end{array}$
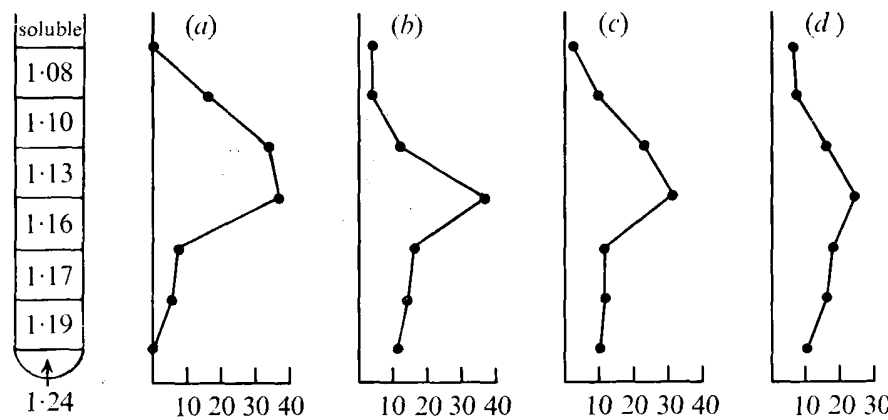

Enzyme activity $(\%)$

Fig. 6. Distribution of marker enzyme and cellulase activities among subcellular fractions of Saprolegnia monoica: (a) NADH cytochrome $c$ reductase; (b) alkaline phosphatase; (c) cellulase; (d) $\mathrm{Mg}^{2+}$-dependent ATPase (plus oligomycin). Cytoplasmic particles were prepared as described in Methods and centrifuged on a discontinuous density sucrose gradient. For each enzyme, activities are expressed as a percentage of the total activity of that enzyme in the gradient.

$\mathrm{MgCl}_{2}$ in the buffer resulted in a shift of cellulase from density I $\cdot \mathrm{IO}$ to $\mathrm{I} \cdot 20 \mathrm{~g} \mathrm{~cm}^{-3}$ (Fig. 5), which indicates that the enzyme is present in the rough endoplasmic reticulum; according to Shore \& MacLachlan (1975) a high $\mathrm{Mg}^{2}$, concentration conserves the integrity of rough endoplasmic reticulum and leads to its sedimentation at high density.

The distribution of cellulase and glucanase activities in the discontinuous sucrose gradient is shown in Table $2 ; 34 \%$ of the glucanase activity and $31 \%$ of the cellulase activity were in the layer of density $\mathrm{I} \cdot \mathrm{I} 6 \mathrm{~g} \mathrm{~cm}^{-3}$.

$\mathrm{Mg}^{2+}$-stimulated ATPase (a plasma membrane marker) showed a higher concentration at the bottom than at the top of the gradient; NADH cytochrome $c$ reductase (an endoplasmic reticulum marker) was mainly located near the top of the gradient (Fig. 6). Alkaline phosphatase, demonstrated in situ in Achlya dictyosomes (Dargent, 1975), sedimented at medium density $\left(\mathrm{I} \cdot \mathrm{I} 6 \mathrm{~g} \mathrm{~cm}^{-3}\right)$, which corresponds to the maximum of cellulase and glucanase activities found in the gradient. Electron microscopy of the $\mathrm{I} \cdot \mathrm{I} 6 \mathrm{~g} \mathrm{~cm}^{-3}$ fraction, the richest in 'morphogen' hydrolases, showed dictyosomes that had probably been dissociated during homogenization. Cytoplasmic vesicles were also present and these were of a similar size to those found in the growing centres (apex and branch sites) (Fig. 7). The $1 \cdot 13 \mathrm{~g} \mathrm{~cm}^{-3}$ fraction showed larger vesicles which could be fragments of endoplasmic reticulum or tonoplast. The $1 \cdot 20 \mathrm{~g} \mathrm{~cm}^{-3}$ fraction showed double membrane vesicles which may have been associated with plasma membrane. A few dictyosomes were also present. 

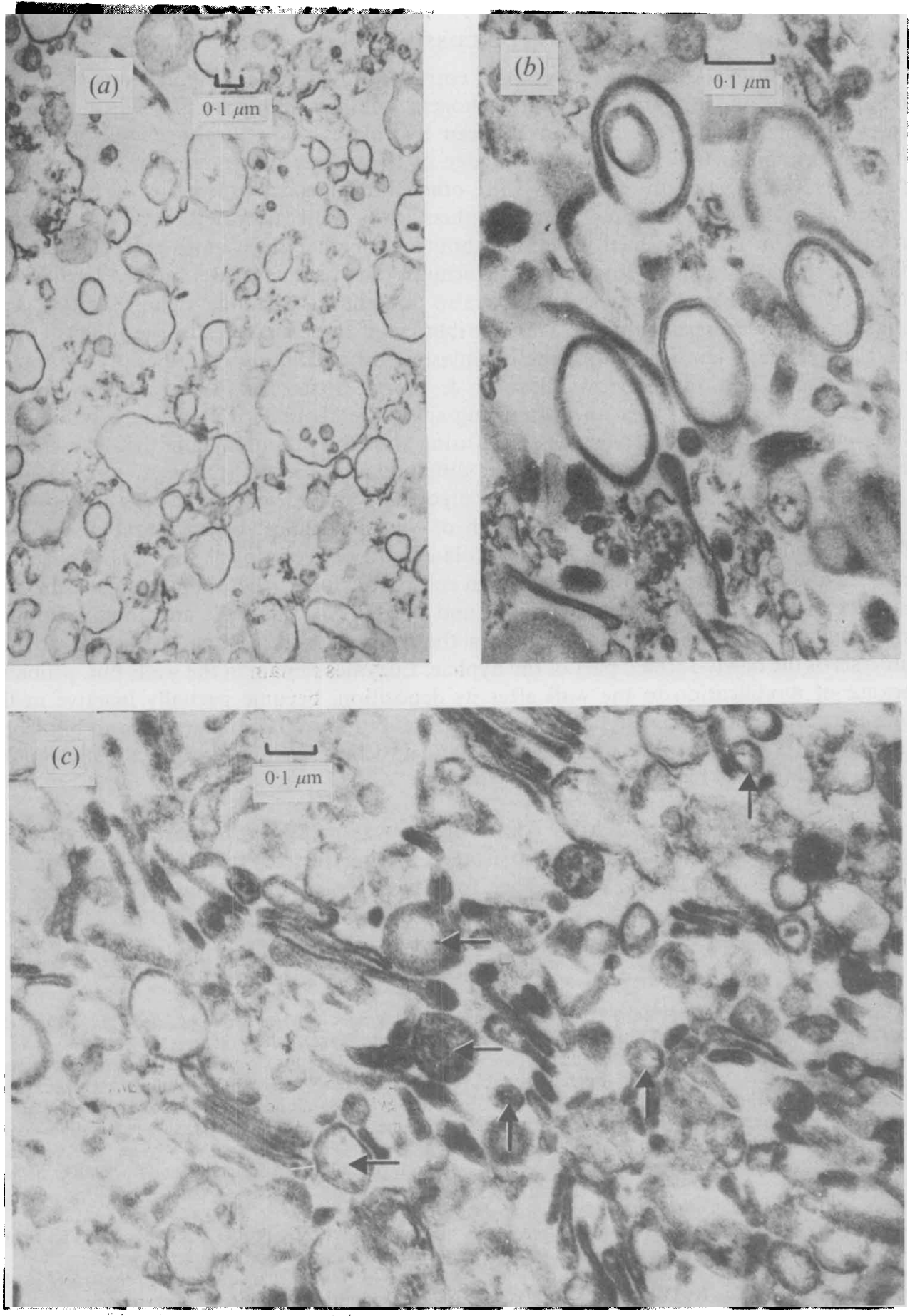

Fig. 7. Electron micrographs of cytoplasmic membranes obtained by centrifugation in a discontinuous density sucrose gradient. (a) Light membranes, endoplasmic reticulum and tonoplast (interface $\mathrm{I} \cdot 08 / \mathrm{I} \cdot 13 \mathrm{~g} \mathrm{~cm}^{-3}$ ). (b) Plasma membrane contaminated by isolated Golgi saccules (interface $\mathrm{I} \cdot \mathrm{I} 6 / \mathrm{I} \cdot 20 \mathrm{~g} \mathrm{~cm}^{-3}$ ). (c) Dictyosomes and Golgi-derived cytoplasmic vesicles (interface $\left.I: 13 / 1 \cdot 16 \mathrm{~g} \mathrm{~cm}^{-3}\right)$. Horizontal arrows indicate large vesicles and vertical arrows indicate small ones. 


\section{DISCUSSION}

Previous results (Fèvre, 1972) showed a correlation between the hyphal morphogenesis of Saprolegnia and the activity of 'morphogen' enzymes (cellulase and glucanase). The present results confirm the relation between hydrolases and morphogenesis. Glucanase and cellulase are mainly localized at the edge of the colony where growth and branching of the hyphae occur. In common with other fungal species, hyphae of Saprolegnia contain enzymes which can hydrolyse their own wall polymers. Autolysis occurs preferentially in newly-formed walls; and branched hyphae have more autolytic enzymes than unbranched hyphae. Intracellular glucanase and cellulase are mainly localized in the Golgi apparatus although they are also present in fractions rich in endoplasmic reticulum and plasma membrane. The distribution of these enzymes in the fungus colony and the hyphae is consistent with the cytoplasmic differentiation described by cytologists (Grove \& Bracker, 1970; Grove, Bracker \& Morré, 1970; Heath, Gay \& Greenwood, 1971). Growth centres (apex and branching sites) are characterized by an accumulation of vesicles derived from dictyosomes and fusing with the plasma membrane. These apical vesicles are involved in wall growth of the differentiation centres (Dargent, 1972; Mullins \& Ellis, 1974) where they probably secrete precursors and enzymes necessary for growth.

The present results give some indication of the biochemical organization of the apex of Saprolegnia. Dictyosomes, rich in hydrolases and derived apical vesicles, may secrete cellulase and glucanase into the walls. By an endo-mechanism, these 'morphogen' enzymes may act on the wall polymers, softening and plasticizing the wall, and thus permitting extension and growth. Enzymes trapped in the wall network may be responsible for the autolysis of the newly-formed part of the hyphae. Enzymes remain in the walls but, probably because of modification to the wall after its deposition, become partially inactive in the older part of the mycelium. Lytic enzymes are essential to wall growth (apex and branches) but wall synthesis must occur simultaneously and a 'delicate balance' must exist (BartinickiGarcia \& Lippman, 1972).

The technical assistance of Miss Aline Effosse was greatly appreciated. I would also like to thank Dr C. Dumas for his assistance in the electron microscope analysis and Dr J. P. Larpent and Dr G. W. Gooday for their helpful suggestions in reviewing the paper.

\section{REFERENCES}

Bartnicki-Garcia, S. \& Lippman, E. (1972). The bursting tendency of hyphal tips of fungi: presumptive evidence for a delicate balance between wall synthesis and wall lysis in apical growth. Journal of General Microbiology 73, 487-500.

BARRAS, D. R. (1972). A $\beta$-glucan endo-hydrolase from Schizosaccharomyces pombe and its role in cell wall growth. Antonie van Leeuwenhoek 38, 65-80.

CORTAT, M. (197I). Localisation intracellulaire et fonction des $\beta$-1,3-glucanases lors du bourgeonnement chez Saccharomyces cerevisiae. Thesis, University of Zurich.

Courtois, J. E. \& BUI, K. D. (I967). Recherches sur le dosage des cellulases et hemicellulases dans les preparations pharmaceutiques. IV. Emploi de l'hydroxyethylcellulose comme substrat. Annales de pharmacie 25, 18I-190.

DARGENT, R. (1972). Sur l'ultrastructure des hyphes en croissance du Mucor mucedo L. et la différenciation de leurs ramifications. Comptes rendus hebdomadaire des séances de l'Académie des sciences $275 \mathrm{D}, 1485-1488$.

DARGENT, R. (1975). Sur l'ultrastructure des hyphes en croissance de l'Achlya bisexualis Coker. Mise en évidence d'une secretion polysaccharidique et d'une activité phosphatasique alcaline dans l'appareil de Golgi et au niveau des vesicules cytoplasmiques apicales. Comptes rendus hebdomadaire des séances de l'Académie des sciences 280, 1445-I448.

FaIRBAIRN, N.J. (1953). A modified anthrone reagent. Chemistry and Industry $72,86$.

FÈvRE, M. (1972). Contribution to the study of the determination of mycelium branching of Saprolegnia monoica Pringsheim. Zeitschrift für Pflanzenphysiologie 68, I-10.

FÈVRE, M. (1976). Recherches sur la déterminisme de la morphogenèse hyphale. Aspects enzymatiques de la croissance et de la ramification des hyphes de Saprolegnia monoica Pringsheim. Thèse Doctorat d'Etat, Université de Lyon. 
Fèvre, M., Turian, G. \& Larpent, J. P. (I974). Bourgeonnements et croissance hyphale fongiques. Homologies structurales et fonctionnelles, modeles Neurospora et Saprolegnia. Physiologie Végétale $13,23-38$.

Fleet, G. H. \& Phaff, H. J. (1974). Glucanases in Schizosaccharomyces. Isolation and properties of the cell wall associated $\beta$-1,3-glucanase. Journal of Biological Chemistry 249, 1717-1728.

Grove, S. N. \& Bracker, C. E. (1970). Protoplasmic organization of hyphal tips among fungi: vesicles and spitzenkörper. Journal of Bacteriology ro4, 989-1009.

Grove, S. N., Bracker, C. E. \& Morré, D. J. (1970). An ultrastructural basis for hyphal tip growth in Pythium ultimum. American Journal of Botany 57, 245-266.

Heath, J. B., Gay, J. L. \& Greenwood, A. D. (197I). Cell wall formation in the Saprolegniales: cytoplasmic vesicles underlying developing walls. Journal of General Microbiology 65, 225-232.

KULAEV, I. S. (1973). The enzyme of polyphosphate metabolism in protoplast and some subcellular structures of Neurospora crassa. In Yeast, Mould and Plant Protoplasts, pp. 259-273. Edited by J. R. Villanueva, I. Garcia-Acha, S. Gascon and F. Uruburu. London and New York: Academic Press.

LoWry, O. H., Rosebrough, N. J., FarR, A. L. \& Randall, R. J. (1951). Protein measurement with the Folin phenol reagent. Journal of Biological Chemistry 193, 265-275.

MACHLIS, L. (1953). Growth and nutrition of watermolds in the subgenus Euallomyces. II. Optimal composition of the minimal medium. American Journal of Botany 40, 449-460.

Maddox, I. S. \& Hough, J.S. (I97I). Yeast glucanase and mannanase. Journal of the Institute Brewing 77, 44-47.

Mahadevan, P. R. \& MahadkaR, U. R. (1970). Role of enzymes in growth and morphology of Neurospora crassa: cell wall bound enzymes and their possible role in branching. Journal of Bacteriology I0I, 94I-947.

Mehta, N. M. \& Mahadevan, P. R. (1975). Pro- teases of Neurospora crassa: their role in morphology. Indian Journal of Experimental Biology I3, I3I-I34.

MilleR, G. L. (1959). Use of dinitrosalycilic acid reagent for determination of reducing sugar. Analytical Chemistry 31, 426-428.

MORRÉ, D. J. (I97I). Isolation of Golgi apparatus. Methods in Enzymology XXII, 130-I48.

Mullins, J. T. (1973). Lateral branch formation and cellulase production in the water molds. Mycologia 65, 1007-1014.

Mullins, J. T. \& Ellis, A. E. (1974). Sexual morphogenesis in Achlya: ultrastructural basis for the hormonal induction of antheridial hyphae. Proceedings of the National Academy of Sciences of the United States of America 71, 1347-1350.

Nombela, C., Uruburu, F. \& Villanueva, J. R. (1974). Studies on membranes isolated from extracts of Fusarium culmorum. Journal of General Microbiology 81, 247-254.

PAge, W. J. \& Stock, J. J. (I974). Sequential action of cell wall hydrolases in the germination and outgrowth of Microsporum gypseum macroconidia. Canadian Journal of Microbiology 20, 483-489.

SchurR, A. \& YAGIL, E. (I97I). Regulation and characterization of acid and alkaline phosphatase in yeast. Journal of General Microbiology $\mathbf{6 5}$, 29I-303.

Shore, G. \& Maclachlan, G. A. (1975). The site of cellulose synthesis. Hormone treatment alters the intracellular location of alkali-insoluble $\beta$-I,4glucan (cellulose) synthetase activities. Journal of Cell Biology 64, 557-57I.

Thomas, D. S. D. \& Mullins, J. T. (1967). Role of enzymatic wall softening in plant morphogenesis. Hormonal induction in Achlya. Science 156, 84-85.

Thomas, D. S. D. \& Mullins, J. T. (I969). Cellulase induction and wall extension in the water mold Achlya ambisexualis. Physiologia plantarum 22, 347-353.

TOLBERT, N. E. (1974). Isolation of subcellular organelles of metabolism on isopycnic sucrose gradients. Methods in Enzymology XXXI, 734-745. 